\title{
Clomazone safenering with dietholate, bentazon protection against ALS inhibitors, and seed quality cost due to weed resistance
}

\author{
Leonardo Bianco de Carvalho \\ São Paulo State University, Jaboticabal, SP, Brazil. Email: leonardo.carvalho@unesp.br.
}

In a current research, SCHMITZ et al. (2018) elucidated the possibility of using the herbicide clomazone associated to the safener dietolate to control ryegrass and wild radish resistance to herbicides inhibitors of EPSPs, ACCase, and ALS in wheat crops. Basically, authors tested doses of dietholate ranged from 120 to $480 \mathrm{~g}$ (for each $100 \mathrm{~kg}$ of wheat seeds cv. Itaipu) and three doses of clomazone (198, 396, and $594 \mathrm{~g} \mathrm{ha}^{-1}$. Authors found treatment of wheat seeds with dietholate did not interfere in ryegrass control and wild radish by clomazone applied in pre-emergence. Moreover, even applying at low doses, clomazone controlled ryegrass and it can be used to control resistant biotypes to EPSPS, ALS, and ACCase inhibitors.

MARCHIORETTO \& DAL MAGRO (2018) found the addition of bentazon to the herbicides cloransulam or imazethapyr decreased the phytotoxicity caused to the bean crop, and did not alter the weed control, with no antagonism of the herbicide mixture. In addition, the crop response was dependent on the cultivar, in spite of both cultivars Agronorte (Anfc9) and IPR Uirapuru tolerated the herbicides. To reach this conclusion, authors performed a field study where the herbicides cloransulam and imazethapyr were tested alone and in combination with bentazon for comparison with a weed and infested control in two bean cultivars.

COSTA et al. (2018) hypothesized the resistance to glyphosate could provide a penalty on seed quality of glyphosate-resistant Conyza bonariensis. Authors performing tests for seed viability and seed vigor under controlled conditions. Biotypes susceptible and resistant to glyphosate were tested but no difference occurred between them regarding on seed germination and embryo viability. However, the percentage of seed germination of the $\mathrm{R}$ biotype was reduced under experimental conditions using the cold test, the accelerated aging test, and the high-temperature stress test. In conclusion, authors indicated they found evidences that glyphosate-resistance is responsible for a penalty on seed quality of $C$. bonariensis.

\section{REFERENCES}

COSTA FR et al. 2018. Can seed quality of hairy fleabane be reduced due to glyphosate resistance? Revista de Ciências Agroveterinárias 17: 136-141.

MARCHIORETTO LDR \& DAL MAGRO T. 2018. Efeito protetor do bentazon sobre a fitotoxicidade de herbicidas inibidores de ALS em duas cultivares de feijoeiro. Revista de Ciências Agroveterinárias 17: 77-82.

SCHMITZ MF et al. 2018. Uso de clomazone associado ao safener dietholate para o manejo de plantas na cultura do trigo. Revista de Ciências Agroveterinárias 17: 2-11. 